\title{
Reply to a correspondence addressing the European guideline for treatment of atopic eczema, functional textiles and the CLOTHES trial
}

Wollenberg, Andreas ; Schmid-Grendelmeier, Peter ; Christen-Zäch, Stephanie ; Ring, Johannes

\begin{abstract}
We have read with interest the respectfully written correspondence by Wüthrich et al. regarding antimicrobial silk textiles for atopic dermatitis (AD) (1). Though it was submitted as a comment to the European consensus-based S2k guidelines on treatment of atopic eczema (2,3), it is discussing in $70 \%$ of its length the CLOTHES trial - published in two non-JEADV-publications which we have neither designed nor authored $(4,5)$.
\end{abstract}

DOI: https://doi.org/10.1111/jdv.15384

Posted at the Zurich Open Repository and Archive, University of Zurich

ZORA URL: https://doi.org/10.5167/uzh-160462

Journal Article

Accepted Version

Originally published at:

Wollenberg, Andreas; Schmid-Grendelmeier, Peter; Christen-Zäch, Stephanie; Ring, Johannes (2019). Reply to a correspondence addressing the European guideline for treatment of atopic eczema, functional textiles and the CLOTHES trial. Journal of the European Academy of Dermatology and Venerology, 33(4):e153-e154.

DOI: https://doi.org/10.1111/jdv.15384 
Article type : Letter to Editor

Reply to a correspondence addressing the European guideline for treatment of atopic eczema, functional textiles and the CLOTHES trial

Andreas Wollenberg ${ }^{1}$

Peter Schmid-Grendelmeier ${ }^{2}$

Stephanie Christen-Zäch ${ }^{3}$

Johannes Ring ${ }^{4}$

${ }^{1}$ Department Dermatology and Allergy, Ludwig-Maximilian University, Munich, Germany and Klinik Thalkirchner Straße, Munich, Germany

${ }^{2}$ Allergy Unit, Department of Dermatology, University of Zurich, Switzerland and Christine Kühne Center for Allergy research and Educaction CK-CARE, Davos, Switzerland

${ }^{3}$ Pediatric Dermatology Unit, Departments of Dermatology and Pediatrics, Centre Hospitalier Universitaire Vaudois, Lausanne, Switzerland

${ }^{4}$ Department Dermatology and Allergy Biederstein, Technische Universität München, Munich, Germany and Christine Kühne-Center for Allergy Research and Education (CK-CARE), Davos

Correspondence to:

Prof. Dr. med. Dr. h.c. Andreas Wollenberg

Department of Dermatology and Allergology

Ludwig-Maximilian University

Frauenlobstr. 9-11, D-80337 Munich

Email: wollenberg@Irz.uni-muenchen.de

This article has been accepted for publication and undergone full peer review but has not been through the copyediting, typesetting, pagination and proofreading process, which may lead to differences between this version and the Version of Record. Please cite this article as doi: $10.1111 / j d v .15384$

This article is protected by copyright. All rights reserved. 
We have read with interest the respectfully written correspondence by Wüthrich et al. regarding antimicrobial silk textiles for atopic dermatitis (AD) (1). Though it was submitted as a comment to the European consensus-based S2k guidelines on treatment of atopic eczema $(2,3)$, it is discussing in $70 \%$ of its length the CLOTHES trial - published in two non-JEADV-publications which we have neither designed nor authored $(4,5)$.

Wüthrich et al. have correctly realized that, based on current evidence, the S2k guidelines author group has not issued a recommendation for or against silk clothing anymore (3), whereas the ETFAD position paper published 2016 still does (6). Silver coated textiles are still recommended in Fig. 1 of the European consensus-based S2k guidelines in mild, moderate and severe AD for both adults and children $(2,3)$. Newer evidence on the durability of silver coated antibacterial garments, which has been published after the March 2017 inclusion deadline of the guidelines, indicates a deliverable antimicrobial activity of silver coated functional textiles (7). The extensive, several decades long, positive clinical experience of the correspondence authors is well noted, and corresponds to their published experience of one week treatment in 14 AD children (8). Both have not been cited in the respective part of the $\mathrm{S} 2 \mathrm{k}$ guidelines (3). The next version of our consenus-based guidelines may incorporate additional data.

We feel that the majority of the correspondence authors' comments should have been filed long ago to the authors of the CLOTHES trial in the respective journals, but we will nevertheless try to address these based on published knowledge and what seems feasible in a short response:

a) The CLOTHES trial was designed as a pragmatic trial mimicking real life conditions and included 300 children. Even if the garments should be worn as much as possible, the minimal compliance requirement of participants makes sense to be as low as clinical reality.

b) In our opinion, the therapeutic decision for long-term antibacterial intervention should include a long-term estimation of disease severity. The NESS has probably been chosen as one of the inclusion criteria for the CLOTHES trial, because it is a validated epidemiological tool for assessing eczema severity over the last 12 months, and not just the current objective signs of AD. In addition, there had to be lesions that could be treated and assessed.

c) A different trial with different inclusion criteria might have shown different results. This may or may not be proven by conducting a new trial, and we would like to include the results in the next version of the guidelines.

This article is protected by copyright. All rights reserved. 
4) For all other methodological aspects of the CLOTHES trial, we suggest writing a correspondence to PloS Med so that these aspects may receive the attention which they deserve, as well as an accurate reply by the CLOTHES trial authors.

In conclusion, the field of functional textiles is interesting and fast moving, and the section authors, as well as the entire guidelines group will happily include additional evidence in the next version of the guidelines.

\section{References}

(1) Wüthrich B, Senti G, Kündig TM. Correspondence. J Eur Acad Derm Venereol, in press.

(2) Wollenberg A, Barbarot S, Bieber T, et al. Consensus-based European guidelines for treatment of atopic eczema (atopic dermatitis) in adults and children: part I. J Eur Acad Dermatol Venereol 2018; 32: 657-682.

(3) Wollenberg A, Barbarot S, Bieber T, et al. Consensus-based European guidelines for treatment of atopic eczema (atopic dermatitis) in adults and children: part II. J Eur Acad Dermatol Venereol 2018; 32: 850-878.

(4) Thomas KS, Bradshaw LE, Sach TH, Cowdell F, Batchelor JM, Lawton S, et al. Randomised controlled trial of silk therapeutic garments for the management of atopic eczema in children: the CLOTHES trial. Health Technol Assess 2017; 21: 1-260.

(5) Thomas KS, Bradshaw LE, Sach TH, et al. Silk garments plus standard care for treating eczema in children: a randomized, controlled, observer-blind, pragmatic trial (CLOTHES Trial). PloS Med 2017; 14: e1002280.

(6) Wollenberg A, Oranje A, Deleuran M, et al. ETFAD/EADV Eczema task force 2015 position paper on diagnosis and treatment of atopic dermatitis in adult and paediatric patients. $J$ Eur Acad Derm Venenreol 2016; 30: 729-747.

(7) Srour J, Berg E, Mahltig B, Smolik T, Wollenberg A. Evaluation of antimicrobial textiles for atopic dermatitis. J Eur Acad Dermatol Venereol. 2018; Jun 12. doi: 10.1111/jdv.15123.

(8) Senti G, Steinmann LS, Fischer B, et al. Antimicrobial Silk Clothing in the Treatment of Atopic Dermatitis Proves Comparable to Topical Corticosteroid Treatment. Dermatology 2006; 213: 228233.

This article is protected by copyright. All rights reserved. 
Andreas Wollenberg

Peter Schmid-Grendelmeier

Stephanie Christen-Zäch

Johannes Ring

Prof. Dr. med. Dr. h.c. A. Wollenberg

Dept. of Dermatology and Allergy

Ludwig Maximilian University

Frauenlobstr. 9-11

80337 Munich, Germany

Tel. +49-89-4400-56251

E-Mail: wollenberg@Irz.uni-muenchen.de

This article is protected by copyright. All rights reserved. 